\title{
Isolasi dan Identifikasi Bakteri Termofilik dari Sumber Air Panas di Moso Distrik Muara Tami Kota Jayapura Provinsi Papua
}

\author{
DIRK Y.P. RUNTUBOI, TRI GUNAEDI, MARIA SIMONAPENDI, NADYA N.L. PAKPAHAN \\ Jurusan Biologi, FMIPA Universitas Cenderawasih, Jayapura, Papua
}

Diterima: 22 Agustus 2018 - Disetujui: 28 September 2018

(C) 2018 Jurusan Biologi FMIPA Universitas Cenderawasih

\begin{abstract}
Thermophilic bacteria are bacteria that are able to survive in environmental conditions with high temperatures. Thermophilic bacteria are one of the important sources of thermostable enzymes that can be isolated from geothermal environments such as hot springs with temperatures ranging from $50-80{ }^{\circ} \mathrm{C}$. Aims of the study to isolate and identify local isolates of thermophilic bacteria from hot springs in Moso Muara Tami District, Papua. The results showed that 7 isolates (A1, A2, A3, A4, B1, B2, and B3) that were isolated and identified based on phenotypic characters were included in the genus Bacillus.
\end{abstract}

Key words: Thermophilic, characterization, isolation, identification, phenotypic.

\section{PENDAHULUAN}

Indonesia memiliki sekurangnnya 10 ribu jenis mikroorganisme terutama bakteri yang diperkirakan hidup secara alami (Kurnia, 2008). Perkembangan bioteknologi akhir-akhir ini khususnya bakteri telah digunakan untuk berbagai tujuan, misalnya sebagai agen penghasil protein dan enzim-enzim penting yang telah dimanfaatkan dunia, agen-agen dalam bioteknologi modern dan rekayasa genetik, agen pengendali hama dan penyakit, agen bioremediasi dan biodegaradasi bahan pencemar. Bakteri termofilik merupakan salah satu penghasil enzim termostabil yang dapat diisolasi dari lingkungan geothermal seperti sumber air panas dan mampu hidup dengan suhu optimal berkisar antara 50-80 ${ }^{\circ} \mathrm{C}$ (Agustien, 2010; Zuridah et al., 2011; Thieman \& Michael, 20113). Enzim-enzim potensial telah

* Alamat korespondensi:

PS. Biologi, Jurusan Biologi, FMIPA Uncen. Jl. Kamp.

Wolker, Waena, Jayapura, Papua. Telp./fax.:

+62967572115. e-mail: diki_runtuboi@yahoo.com berhasil diidentifikasi dari bakteri termofilik seperti amylase, DNA polymerase, xylanase, kitinase, lipase dan protease (Dominguez et al., 2005; Zang et al., 2007; Bozoglu et al., 2015; Scully \& Orlygsson, 2015; Ladeira et al., 2015).

Berbagai isolat lokal bakteri termofilik potensial di Indonesia telah diisolasi dan diidentifikasi dari beberapa sumber air panas antara lain di Pulau Jawa, Sumatera (Linawati, 2005; Agustini, 2006; Muharni, 2009; Agustien, 2010; Hastuti et al., 2012) dan di Papua khususnya iolasi bakteri termofilik dari sumber air panas di Merauke (Runtuboi et al., 2014; Patasik et al., 2015). Papua memiliki beberapa sumber air panas selain di Merauke salah satunya di Moso (Perbatasan RIPNG) dengan jarak $40 \mathrm{~km}$ dari Kota Jayapura, suhu pada permukaan sumber air panas di Moso berkisar $73{ }^{\circ} \mathrm{C}$.

Peran enzim termostabil dalam bioteknologi modern dewasa ini sangat besar, maka perlu dilakukan penelitian yang bertujuan untuk mengisolasi dan menidentifikasi isolate-isolat lokal bakteri termofilik sebagai sumber enzim potensial khususnya di Papua yang belum banyak diteliti. 


\section{METODE PENELITIAN}

\section{Waktu dan Tempat}

Penelitian ini dilaksanakan selama 6 bulan, dimulai dari bulan Februari sampai Juli 2018 di Laboratorium Mikrobiologi FMIPA Universitas Cenderawasih. Sampel bakteri berasal dari sumber air panas Moso Distrik Muara Tami Kota Jayapura Papua yang merupakan koleksi Laboratorium Jurusan Biologi, Universitas Cenderawasih, Jayapura.

\section{Alat dan Bahan}

Alat yang digunakan antara lain Laminar Air Flow (LAF), inkubator, vortex, lemari pendingin, autoklaf, timbangan analitik, berbagai macam standar peralatan gelas, mikro pipet, $\mathrm{pH}$ meter, thermometer, serta peralatan penunjang lainnya. Bahan yang digunakan antara lain medium Plate Count Agar (PCA), nutrient broth (NB), media uji fisiologis, Medium Triple Sugar Iron Agar (TSIA), medium Simmon's sitrat, medium semi solid, medium MR-VP broth, reagen pewarnaan Gram (Kristal violet, $\mathrm{Kl}$ dan $\mathrm{I}_{2}$, Aseton $+\mathrm{EtOH}$, Safranin) pewarna endospora (Malachite Green dan Safranin).

\section{Prosedur Penelitian}

Penelitian ini terdiri dari beberapa tahapan yakni isolasi, pengamatan makroskopis (karakteristik koloni), pengamatan mikroskopis (bentuk sel, sifat Gram dan spora) dan uji biokimia.

\section{Isolasi Bakteri Termofilik}

Sampel air panas diambil dari sumber air panas di Moso dengan menggunakan botol sampel steril sebanyak $100 \mathrm{ml}$ dari 2 titik pengambilan dengan ulangan sebanyak 3 kali. Dilakukan pengukuran $\mathrm{pH}$ air dengan kertas $\mathrm{pH}$ universal dan pencatatan fisik air seperti: bau, rasa dan warna. Sampel air disimpan dalam termos dan dibawa langsung ke laboratorium untuk dianalisis sebelum 24 jam dari waktu pengambilan sampel. Selanjutnya dilakukan inokulasi pada Media PCA dan diinkubasi pada suhu $50{ }^{\circ} \mathrm{C}$ selama 24 jam (Krieg et al., 2010; Patasik et al., 2015; Bozoglu et al., 2015). Koloni yang tumbuh diisolasi dan dikultur kembali untuk mendapatkan isolat murni. Identifikasi dilakukan dengan mangamati karakter makroskopis, mikroskopis dan karakteri biokimia yang meliputi krakter koloni, sifat Gram, spora, fermentasi karbohidrat (glukosa, laktosa, fruktosa, maltose) Produksi $\mathrm{H}_{2} \mathrm{~S}$, produksi indol,

Tabel 1. Hasil pengamatan Karakteristik Makroskopis pada Media Padat PCA.

\begin{tabular}{cclllll}
\hline Isolat & \multicolumn{5}{c}{ Karakter } \\
\cline { 2 - 6 } & Ukuran & Bentuk Koloni & Elevasi & \multicolumn{1}{c}{ Permukaan } & Margins & Warna \\
\hline A1 & Kecil & Bulat beraturan & Convex & Halus mengkilap & rata & Putih \\
A2 & Kecil & Rizoid & Umbonate & Kasar & bergelombang & Putih \\
A3 & Kecil & Iregular & Convex & Halus mengkilap & berlekuk & Putih \\
A4 & Kecil & Irregular & Convex & Halus mengkilap & rata & Putih \\
B1 & Kecil & Bulat beraturan & Convex & Halus mengkilap & rata & Kuning \\
B2 & Sedang & Iregular & Umbonate & Berkerut & berlekuk & Putih \\
B3 & Sedang & Iregular & Flat & Halus mengkilap & bergerigi & Putih \\
\hline
\end{tabular}

Tabel 2. Hasil Pengamatan Mikroskopis dan uji katalse.

\begin{tabular}{llccccccc}
\hline \multirow{2}{*}{ No } & \multicolumn{7}{c}{ Karakter } & \multicolumn{7}{c}{ Isolat } \\
\cline { 3 - 8 } & & A1 & A2 & A3 & A4 & B1 & B2 & B3 \\
\hline 1. & Bentuk sel batang & + & + & + & + & + & + & + \\
2. & Gram & + & + & + & + & + & + & + \\
4. & Endospora & + & + & + & + & + & + & + \\
5. & Katalase & + & - & + & - & + & + & + \\
\hline
\end{tabular}


produksi katalase, uji metil merah, uji VogesProkauer, Uji TSI dan Uji Simon's sitrat (Capucino \& Sherman, 1992).

\section{HASIL DAN PEMBAHASAN}

\section{Karakteristik Sampel Air}

Sampel air diperoleh dari dua titik koordinat yakni, I pada koordinat $2^{\circ} 40^{\prime} 36,288^{\prime \prime} S$ dan $144^{\circ} 37^{\prime} 26,274^{\prime \prime} \mathrm{E}$, titik II diambil pada koordinat $2^{\circ} 40^{\prime} 36,60^{\prime \prime} \quad S$ dan $140^{\circ} 57^{\prime} 26,082^{\prime \prime}$ E. Hasil pengamatan yang dilakukan terhadap parameter fisika menunjukkan bahwa suhu pada kedua titik pengambilan sampel tersebut sama, yaitu sekitar $73{ }^{\circ} \mathrm{C}$. Pada lokasi tersebut aroma belerang dan lumpur yang sangat terasa, lumpur disekitar air panas tersebut hangat, warna air panas jernih (bening) dengan $\mathrm{pH}$ 6. Gambaran kondisi lingkungan tersebut merupakan habitat yang baik bagi bakteri termofilik. Bakteri termofilik tumbuh pada suhu $45-80{ }^{\circ} \mathrm{C}$, bahkan ada yang mampu tumbuh hingga $100{ }^{\circ} \mathrm{C}$. Menurut Lestari (2000), kemampuan bakteri termofilik untuk hidup pada kondisi suhu lingkungan yang tinggi disebabkan karena bakteri termofilik memiliki enzim-enzim

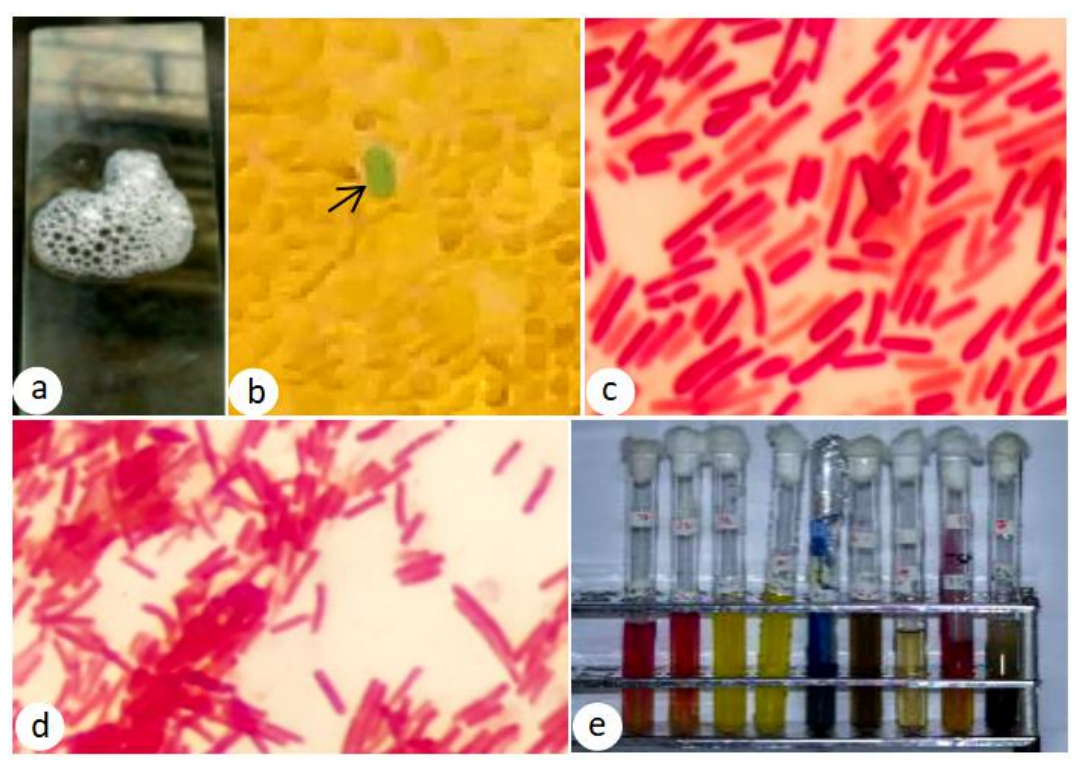

Gambar 1. Karakteristik isolat bakteri. (a). Katalase Positif pada isolate A1, (b) adalah gambar spora pada isolate A3, (c) dan (d) adalah morfologi sel (bentuk batang) dan sifat gram + pada isolate B1dan B2, (e) hasil uji biokimia pada isolate A4. dan protein yang hampir semuanya stabil terhadap panas bila dibandingkan dengan bakteri mesofilik.

\section{Isolasi dan Pengamatan Makroskopis}

Hasil isolasi bakteri dari sumber air panas diperoleh 7 isolat dimana 4 isolat diperoleh dari titik I dan 3 isolat dari titik II. Isolat dari titik I diberi kode $\mathrm{A}(\mathrm{A} 1, \mathrm{~A} 2, \mathrm{~A} 3$ dan $\mathrm{A} 4)$, isolate dari titik II diberi kode B (B1, B2, dab B3). Pengamatan koloni pada kultur murni yang ditumbuhkan pada media padat Plate Count Agar (PCA) sangat bervariasi (Tabel 1).

\section{Hasil Pengamatan Mikroskopis dan Sifat Katalse}

Isolat-isolat bakteri tersebut selanjutnya diidentifikasi secara mikroskopis terhadap beberapa karakter seperti sifat Gram, bentuk sel, ada tidaknya endospore dan uji katalse (Tabel 2). Titik sumber air panas yang berbeda dapat mempengaruhi banyaknya jumlah isolat yang diperoleh sehingga mempengaruhi jumlah bakteri pada sumber air panas tersebut. Perbedaan jumlah isolat yang pada masingmasing titik dapat dipengaruhi oleh kondisi lingkungan yang mendukung kehidupan bakteri. Faktor biotik yang terdapat pada lokasi pengambilan sampel diantaranya dedaunan yang gugur, rerumputan, lumut dan sumber organik lain yang menjadi sumber energi bagi mikroorganisme (Rahmadani et al., 2015).

Sifat fisiologis bakteri termofilik terhadap berbagai uji yang diberikan, yaitu uji TSIA, SIM, SC, uji Gula-gula dan MRV ditunjukkan pada table 3 . Hasil pengamatan uji TSIA dilakukan untuk menilai kemampuan bakteri dalam memfermentasi glukosa, laktosa dan sukrosa yang ditandai dengan perubahan warna akibat terbentuknya asam pada slant dan butt yang berwarna merah atau kuning, serta terbentuknya gas $\left(\mathrm{H}_{2} \mathrm{~S}\right)$. Dari 7 isolat yang telah diisolasi tersebut 
terlihat 2 isolat diantaranya yaitu isoolat A2 dan A4 bersifat negatif atau tidak memfermentasi medium TSIA.

Uji SIM merupakan uji pada media semisolid yang digunakan untuk menilai adanya hidrogen sulfida, timbulnya indol akibat enzim tryptophanase yang ditandai dengan berubahnya larutan kovac menjadi merah dan ada tidaknya pergerakan. Hasil pengamatan menunjukkan bahwa 2 isolate B1 dan B3 memiliki pergerakan dan memperoduksi indol.

Hasil uji Sitrat digunakan untuk melihat kemampuan suatu bakteri menggunakan natrium sitrat sebagai sumber utama metabolisme dan pertumbuhan. Hasil pengamatan memperlihatkan semua isolat (7 isolat) meggunakan sitrat sebagai sumber karbon untuk energi yang ditandai dengan adanya perubahan warna hijau menjadi biru karena penghilangan dan peningkatan $\mathrm{pH}$ pada media (Tuntun \& Huda, 2014). Hasil uji gulagula terlihat bahwa 7 isolat mampu memfermentasi glukosa dan maltose yang ditandai dengan adanya perubahan warna dari biru menjadi kuning sedangkan pada uji MRPV 7 isolat tidak dapat memfermentasi butanadiol (VP) dan Metil Red atau uji MRVP bersifat negatif.

\section{Identifikasi Bakteri}

Secara umum semua isolat memperlihatkan karakter fenotipik yang sangat bervariasi. Namun ada beberapa karakter umum yang ditemukan pada ketujuh isolate yaitu bentuk sel batang dan endospore. Sifat tersebut merupakan karakter umum bakteri dari Genus Bacillus. Menurut Goldman \& Green (2009) Genus Bacillus mewakili kelompok bakteri yang sangat luas dan beragam namun genus ini memiliki satu karakter umum yaitu kemampuan untuk mebentuk endospora dalam kondisi lingkungan yang kurang menguntungkan. Genus ini dibagi kedalam beberapa kelompok besar berdasarkan bentuk sporanya, sifat biokimia dan pertumbuhannya. Morfologi bakteri termofilik genus Bacillus secara mikroskopis berbentuk basil/ batang tunggal atau berpasangan atau menyusun seperti filamen, diameter sel antara $0,4-1,8 \mu \mathrm{m}$ dan panjang sel 0,9-10,0 $\mu \mathrm{m}$, ada yang Gram positif dan Gram negatif, motil dan non motil, menghasilkan spora jika dikultur pada unsur hara yang sesuai, dapat atau tidak memfermentasi karbohidrat atau sukrosa (Tuntun \& Huda, 2014). Bacillus sp mudah tumbuh pada media umum dan media yang diperkaya dengan sifat dan karakteristik yang sangat bervariasi, mulai dari bentuk koloni besar, melingkar, bergelombang, dengan tepi berombak, keriput atau bergelombang dan tekstur koloni yang halus dan kadang-kadang lembab, berlendir atau ada yang mengkilap (Noel et al., 2010; Tuntun \& Huda, 2014).

Tabel 3. Karakteristik Fisiologi (biokimia).

\begin{tabular}{|c|c|c|c|c|c|c|c|}
\hline \multirow[t]{2}{*}{ Nama uji } & \multicolumn{7}{|c|}{ Kode isolat } \\
\hline & A1 & A2 & $\mathrm{A} 3$ & $\mathrm{~A} 4$ & B1 & B2 & B3 \\
\hline TSIA & $\begin{array}{l}\mathrm{m} / \mathrm{k}, \mathrm{g}(-), \\
\mathrm{H}_{2} \mathrm{~S}(-)\end{array}$ & $\begin{array}{l}\mathrm{m} / \mathrm{m}, \mathrm{g}(-), \\
\mathrm{H}_{2} \mathrm{~S}(-)\end{array}$ & $\begin{array}{l}\mathrm{m} / \mathrm{k}, \mathrm{g}(-), \\
\mathrm{H}_{2} \mathrm{~S}(-)\end{array}$ & $\begin{array}{l}\mathrm{m} / \mathrm{m}, \mathrm{g}(-), \\
\mathrm{H}_{2} \mathrm{~S}(-)\end{array}$ & $\begin{array}{l}\mathrm{m} / \mathrm{k}, \mathrm{g}(-), \\
\mathrm{H}_{2} \mathrm{~S}(-)\end{array}$ & $\begin{array}{l}\mathrm{m} / \mathrm{k}, \mathrm{g}(-), \\
\mathrm{H}_{2} \mathrm{~S}_{(-)}\end{array}$ & $\begin{array}{l}\mathrm{m} / \mathrm{k}, \mathrm{g}(-), \\
\mathrm{H}_{2} \mathrm{~S}(-)\end{array}$ \\
\hline SIM &,,--- &,,--- &,,--- &,,--- &,,-++ &,,--- &,,-++ \\
\hline SC & + & + & + & + & + & + & + \\
\hline Glukosa & + & + & + & + & + & + & + \\
\hline Laktosa & - & - & - & - & - & - & - \\
\hline Sukrosa & + & + & + & + & + & + & + \\
\hline Maltosa & + & + & + & + & + & + & + \\
\hline MRVP & - & - & - & - & - & - & - \\
\hline
\end{tabular}

Ket.: - : negatif, +: positif, g: gas, m/k:merah/kuning, TSI: triple sugar Iron Agar, SC: Simmon Citrate, SIM: Sulfur Indol Motility, MR:Methyl Red, VP: Voges Proskouer. 


\section{KESIMPULAN}

Pada penelitian ini Identifikasi dilakukan berdasarkan karakter fenotipik dengan melihat karakteristik makroskopis, mikroskopis dan sifat biokimia sesuai penjelasan berdasarkan Bergey Manual of Systematic Bacteriology Second Edition Volume Four dimana dapat disimpulkan bahwa semua isolate (7 isolat) masuk kedalam genus Bacillus.

Untuk penelitian lanjutan diperlukan identifikasi hingga tingkat jenis dari berbagai isolat yang diperoleh. Disarankan bahwa perlu tindaklanjut karakterisasi uji seperti sifat pertumbuhan dalam berbagai media dan karakter biokimia lainnya yang belum tercakup dalam penelitian ini sehingga dapat dilakukan identifikasi secara taksonomi numerik. Metode lainnya adalah identifikasi secara molekuler berdasarkan gen $16 S$ rRNA.

\section{UCAPAN TERIMA KASIH}

Ucapan terimakasih disampaikan kepada Bapak Rollo atas kontribusinya memfasilitasi seluruh perjalanan untuk pengambilan sampel air panas di Moso. Terima kasih disampaikan kepada Bapak Kepala Kampung Moso yang telah memberi ijin pengambilan sampel air panas. Terima kasih kepada Saudara Illen Aninam atas kontribusinya mendampingi tim peneliti selama proses pengambilan sampel di lapangan dan analisis laboratorium. Terima kasih khususnya kepada Kepala Laboratorium Mikrobiologi Dr. Daniel Lantang, M.Kes. (Periode 2014-2018) yang telah memfasilitasi semua pekerjaan riset di laboratorium Mikrobiologi Universtias Cenderawasih.

\section{DAFTAR PUSTAKA}

Agustien, A. 2010. Isolasi dan optimasi Bacillus sp penghasil protease alkali dan keratinase termostabil serta aplikasinya. [Disertasi]. Universitas Padjadajaran. Bandung.

Agustini, R. 2006. The utilization of thermophilic protease which life in hot spring Cangar Batu Malang. Indo. J. Chem. 6(2): 205-211.
Bozoglu, C., H. Selin, B. Alayar, M. Karadayi, and M. Gullece. 2015. Isolation and moelcular characterization of thermophilic bacteria with xylanase activity from thermal springs in Erzurum. Jurnal of Life Sciences and Technologies. 3(1): 32-36.

Bozoglu, C., H. Selin, B. Alayar, M. Karadayi, and M. Gullece. 2015. Isolation and molecular characterization of thermophilic bacteria with xylanase activity from thermal springs in Erzurum. Jurnal of Life Sciences and Technologies. 3(1): 32-36.

Cappuccino, J.G. and N. Sherman. 1992. Microbiology a laboratory manual. $3^{\text {rd }}$ Edition. The Benjamin/Cummings Publishing Company, Inc. California, USA.

Domingguez, A., L. Pastrana, M.A.S. Longo, M.L. Rual, and M.A. Sanroman. 2005. Lipolytic enzyme productions by Thermus thermophilus HB27 in a stirred tank bioreactor. Biochem. Eng. J. $26: 23$.

Goldman, E. and L.H. Green. 2009. Practical handbook of microbiology $2^{\text {th }}$. CRC Press Taylor \& Francis Group. pp: 309-326.

Hastuti, W., A. Agustien., and Nurmiati. 2012. Screening and characterization of amylo-thermophylic bacteria from Semurup hot springs, Kerinci, Jambi. Jurnal Biologi Universitas Andalas. 1(2): 150-155.

Krieg, N.R., J.T. Staley, D.R. Brown, B.P. Hedlund, B.J. Paster, N.L. Ward, W. Ludwig and W.B. Whitman. 2010. Bargey manual of systematic bacterology. Second Edition Volume Four. Springer. London.

Kurnia, K. 2008. Menyelamatkan mikroorganisme Indonesia. Kunia Organik Farming \& Research. Artikel lepas.

Ladeira, S.A., C. Erica., A.B. Delatorre., J.B. Barbosa, and M.L. Martins. 2015. Cellulase production by thermophilic Bacillus sp. SMIA-2 and its detergent compatibility. Electronik Journal of Biotecnology. 18: 110-115.

Lestari, P. 2000. Eksplorasi enzim termostabil dari mikro termofil. Hayati. 7: 21-25.

Linawati, M.D. 2005. Identifikasi fragmen Gen 16S rRNA pada bakteri termofilik hasil isolasi dari sumber air panas Batu Raden. [Skripsi]. Universitas Diponegoro. Semarang.

Muharni. 2009. Isolasi dan identifikasi bakteri penghasil kitinase dari sumber air panas Danau Ranau Sumatera Selatan. Jurnal Penelitian Sains. 9: 12-15.

Noel, R.K., T. James., Staley., D.R. Brown., P. Brian. Hedlund., B.J. Paster., N.L. Ward, W. Ludwig and W.B. Whitman. 2010. Bergey's manual of systematic bacteriology. Second Edition. Volume Four. The Bacteroidetes, Spirochaetes, Tenericutes (Mollicutes), Acidobacteria, Fibrobacteres, Fusobacteria, Dictyoglomi, Gemmatimonadetes, Lentisphaerae, Verrucomicrobia, Chlamydiae, and Planctomycetes. University of Georgia Athens, GA 30602-2605. USA.

Patasik, I., D.Y.P Runtuboi., T. Gunaedi and Y. Ngili. 2015. Identification and characterization of thermophilic Bacillus sp with protease activity at the fragment of $16 \mathrm{~S}$ rRNA gene of several hot springs in Merauke, PapuaIndonesia. Der Pharma Chemica. 7(7) : 1-10. 
Rahmadani, E.P., A. Agustien dan F.A. Febria. 2015. Isolasi dan karakterisasi bakteri amilotermofilik dari sumber air panas Sungan Medang. Jurnal Biologi Universitas Andalas. 4(1): 119-122.

Runtuboi, D., T. Gunaedi, V. Purnamasari., I. Patasik dan N. Uyo. 2014. Indentifikasi Bacillus thermofilik penghasil protease dari beberapa sumber air panas di Merauke Papua. Prosiding Seminar Nasional Biologi di Jayapura, 7-8 Oktober 2014, hal: 1-6.

Scully, S.M and J. Orlygsson. 2015. Recent advances in second generation ethanol production by thermopilic bacteria. Energies. 8: 1-30.

Thieman, W.J., and A.P. Michael. 2013. Introduction to biotechnology. Pearson. USA.
Tuntun, M dan M. Huda. 2014. Isolasi dan identifikasi bakteri termofilik dari sumber air panas Way Panas Bumi Natar Lampung Selatan. Jurnal Analisis Kesehatan. 3(1): 297-304. Zhang, H., Z. Zhang, J. Li, and S. Cai. 2007. Effects of $\mathrm{Mg}^{2+}$ on supported bilayer membrane on a glassy carbon electrode during membrane formation. International Journal of Electrochemical Science. 2: 788-796.

Zuridah, H., N. Norazwin, S.M Aisyah, M.N.A. Fakhruzzaman and N.A. Zaenathul. 2011. Identification of lipase producing thermophilic bacteria from Malaysian hot springs. African Journal of Microbiology Research. 5(21): 3569-3573. 